\begin{tabular}{r|l|l|l}
$\begin{array}{c}\text { Case Reports in } \\
\text { Gastroenterology }\end{array}$ & $\begin{array}{l}\text { Case Rep Gastroenterol 2010;4:397-398 } \\
\text { DOl: 10.1159/000320574 }\end{array}$ & $\begin{array}{l}\text { Published online: } \\
\text { September 20, 2010 }\end{array}$ & $\begin{array}{l}\text { O 2010 S. Karger AG, Basel } \\
\text { ISSN 1662-0631 } \\
\text { www.karger.com/crg }\end{array}$ \\
\hline
\end{tabular}

This is an Open Access article licensed under the terms of the Creative Commons AttributionNonCommercial-NoDerivs 3.0 License (www.karger.com/OA-license), applicable to the online version of the article only. Distribution for non-commercial purposes only.

\title{
A Case of Chronic Appendicopathy Caused by Parasitic Infection
}

\author{
A.S. Ramsaransing ${ }^{a} \quad$ R.R. Postema ${ }^{b} \quad$ J.L. Simons ${ }^{c}$ \\ ${ }^{\mathrm{a} E}$ Erasmus MC, Rotterdam, ${ }^{\mathrm{b}}$ Ruwaard van Putten Hospital, Spijkenisse, and \\ 'Department of Pathology, Pathan, Rotterdam, The Netherlands
}

\section{Key Words}

Chronic appendicitis · Appendicopathy · Enterobius vermicularis · Parasitic infection

\begin{abstract}
Parasitic infection of the appendix is rarely seen, but should be considered in patients with symptoms of chronic appendicitis. It is rarely associated with histological inflammation of the appendix, therefore radiographic imaging, performed during initial workup, remains unremarkable most of the time.
\end{abstract}

\section{Case Report}

A 13-year-old girl presented to our clinic with a 3-month history of abdominal pain centered in the right lower quadrant, nausea, decreased appetite, weight loss and severe fatigue. She had been admitted to another hospital 3 months earlier for analysis, without satisfactory results.

Abdominal examination showed slight tenderness of the right lower quadrant but was otherwise unremarkable. Serum laboratory tests showed no signs of acute or chronic infection. The remainder of the physical examination was unremarkable.

During the analysis first ultrasonography was performed without signs of appendicitis. Afterwards $\mathrm{CT}$ and MRI of the abdomen were done and showed no abnormalities. We also conducted a colonoscopy which was unremarkable. Because of her persisting symptoms and a family history of 'chronic appendicitis' with similar symptoms, we conducted a laparoscopic inspection of the abdomen. Macroscopic inspection of the appendix showed no signs of inflammation. An appendectomy was performed and the appendix was sent for histopathological examination. The cross-section of the appendix showed a worm with morphologic characteristics of an Enterobius vermicularis (fig. 1). This was later confirmed by a stool culture. The patient fully recovered without persisting symptoms.

\section{Discussion}

Enterobius vermicularis infestation is treated with anthelmintics and re-infection is prevented by implementation of adequate hygiene. Parasitic infection of the appendix 


\begin{tabular}{r|l|l|l}
$\begin{array}{r}\text { Case Reports in } \\
\text { Gastruenterology }\end{array}$ & $\begin{array}{l}\text { Case Rep Gastroenterol 2010;4:397-398 } \\
\text { DOI: 10.1159/000320574 }\end{array}$ & $\begin{array}{l}\text { Published online: } \\
\text { September 20, 2010 }\end{array}$ & $\begin{array}{l}\text { O 2010 S. Karger AG, Basel } \\
\text { ISSN 1662-0631 } \\
\text { www.karger.com/crg }\end{array}$ \\
\hline
\end{tabular}

occurs in $1.4-2.7 \%$ of patients with clinical symptoms of chronic appendicitis $[1,2]$. Association with histological inflammation of the appendix is uncommon, therefore examination of the lumen is important for diagnosing unexplained appendicopathy.

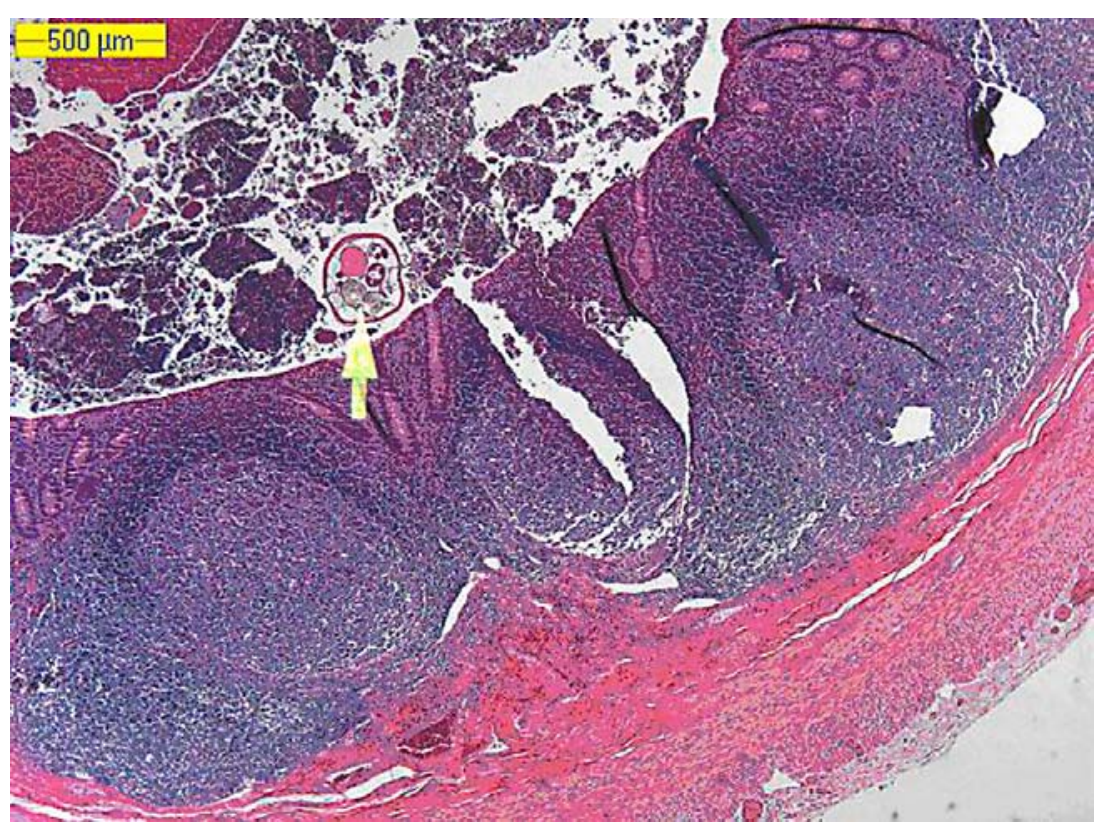

Fig. 1. Microscopic view of the wall and lumen of the appendix with the parasite (arrow).

\section{References}

1 Budd JS, Armstrong C: Role of Enterobius vermicularis in the aetiology of appendicitis. Br J Surg 1987;74:748749.

$\$ 2$ Arca MJ, Gates RL: Clinical manifestations of appendiceal pinworms in children: an institutional experience and a review of the literature. Pediatr Surg Int 2004;20:372-375. 